\title{
Thyroid-like follicular carcinoma of the kidney presenting on a ten year-old prepubertal girl
}

\author{
Lisieux Eyer de Jesus ${ }^{1}$, Celine Fulgêncio ${ }^{1}$, Thais Leve ${ }^{1}$, Samuel Dekermacher ${ }^{1}$ \\ ${ }^{1}$ Departamento de Cirurgia e Urologia Pediátrica, Hospital Federal dos Servidores do Estado, Rio de \\ Janeiro, RJ, Brasil
}

\section{ABSTRACT}

The very rare thyroid-like carcinoma of the kidney (TLCK) is microscopically similar to thyroid follicular cell carcinoma (TFCC). Differential diagnosis with secondary thyroid tumors depends on non-reactivity to immunohistochemical (IHC) markers for TFCC (thyroglobulin - TG and TTF1). We herein describe the fourth Pediatric case in literature and extensively review the subject. Only 29 cases were published to the moment. Most cases were asymptomatic and incidentally detected. Most tumors are hyperechoic and hyperdense with low grade heterogenous enhancement on CT and MRI. Most patients were treated with radical nephrectomy, but partial nephrectomy was used in some cases, apparently with the same results. Metastases are uncommon and apparently do not change prognosis, but follow-ups are limited. Up to the moment, TLCK presents as a low grade malignancy that may be treated exclusively with surgery and frequently with partial kidney renal preservation. A preoperative percutaneous biopsy is a common procedure to investigate atypical tumors in childhood and adult tumors. To recognize the possibility of TLCK is fundamental to avoid unnecessary thyroidectomies in those patients, supposing a primary thyroid tumor.

\section{ARTICLE INFO}

\section{Lisieux Eyer de Jesus}

https://orcid.org/0000-0003-0308-1152

\section{Keywords:}

Kidney Neoplasms; Carcinoma;

Pediatrics

Int Braz J Urol. 2019; 45: 834-42

Submitted for publication:

July 12,2018

\section{Accepted after revision:}

February 24, 2019

Published as Ahead of Print:

May 02, 2019

\section{INTRODUCTION}

Thyroid-like carcinoma of the kidney (TLCK) is microscopically similar to thyroid follicular cell carcinoma (TFCC) and depends on non-reactivity to immunohistochemical (IHC) markers for TFCC (thyroglobulin-TG and TTF1) and on exclusion of other primary renal tumors for diagnosis. We describe a Pediatric case with a literature review.

\section{CLINICAL SCENARIO AND RATIONAL}

Clinical and pathologic findings

A 10 year-old pre-pubertal female presented with abdominal pain and occasional nausea and vomiting for two months. Her physical examination was normal. An abdominal ultrasound showed an encapsulated $82 \times 69 \times 42 \mathrm{~mm}$ solid mass with mixed echogenicity, predominantly hype- 
rechoic, in the medium/superior poles of the right kidney. A thoracoabdominal CT confirmed an exophytic, lobulated, solid, circumscribed $63 \times 60 \times 47 \mathrm{~mm}$ mass in the superior and anterior medium third of the right kidney, with heterogeneous low enhancement after contrast injection. Necrotic and cystic areas were present, abutting but not invading the renal pelvis and hilar vessels. Augmented perihilar and pericaval lymph nodes were present (Figure-1). Her thyroid was functionally normal. No thyroid, ovarian, pelvic, cervical or thoracic tumors were demonstrated.

Right radical nephrectomy and locoregional lymphadenectomy were performed. The

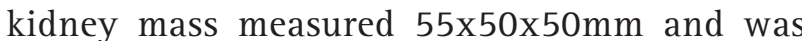
well encapsulated, showing cystic and solid areas (Figure-1). Microscopically the main feature was the strong resemblance to thyroid tissue. At low magnification the tumor was composed of follicles of variable size. The follicles were lined by cuboidal or flattened epithelial cells and the material in the follicles was eosinophilic. The nuclei were round with uniform distribution of chromatin. Calcification, fibrosis, hemorrhage and necrosis were focally seen. The mass was restricted to the kidney, without vascular, adrenal, renal sinus or lymphatic invasion. The lymph nodes showed no metastases. Immunohistochemistry demonstrated non-reactivity for TTF-1 and thyroglobulin. The tumor cells were also non-immunoreactive with CK20, CD 117 and RCC. Other markers were tested with positive results for PAX8, CK7, EMA and vimentin. After 1 year 7 months the patient persists asymptomatic with normal abdominal ultrasounds.

Figure 1 - Thyroid-like carcinoma of the kidney. (A) CT with contrast, showing heterogeneous low grade enhancement of the tumor. (B) Well defined tumor showing cystic, hemorrhagic and solid areas. (C) Follicular architecture with microfollicles and macrofollicles filled with colloid-like material.
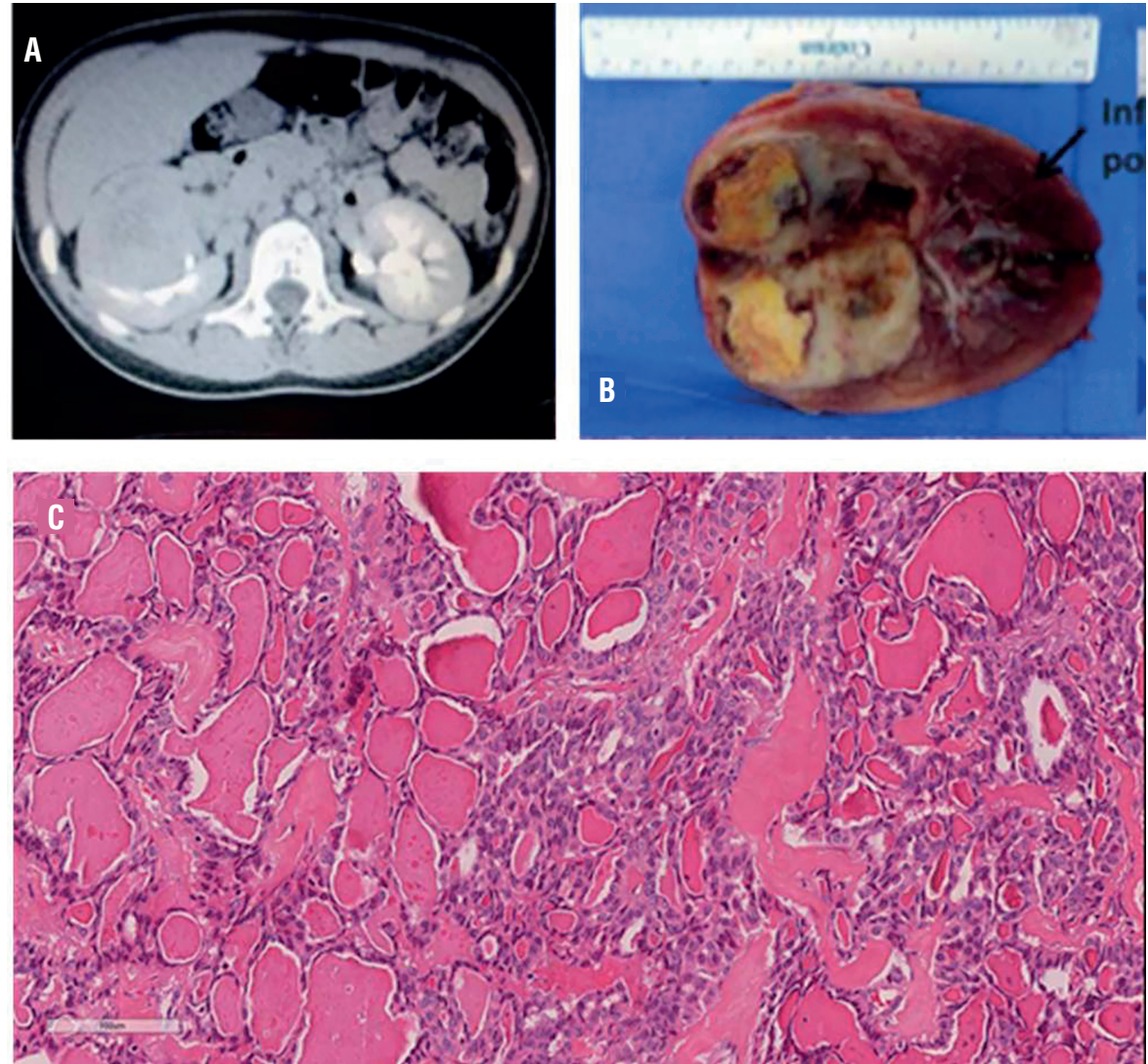


\section{DISCUSSION AND FUTURE PERSPECTIVES}

Twenty-five cases of TLCK have been described. Another 4 are available in Chinese $(n=3)$ and German $(n=1)$. Females predominate (14 females, 6 males, 1 unknown). Ages vary between 19-83 years-old (mean 42.7, median 35). Females tended to be younger (median 32 versus 55 years-old for males). Only 3 other pediatric cases were published (5.3-14 years-old, $2 / 3$ females) (1).

Most cases were asymptomatic, incidentally detected. Approximately $1 / 5$ presented hematuria and/or flank pain. One patient each showed weight loss, anemia and hypertension (cured after resection of a perihilar tumor) (2). Many tumors were associated with previous malignancy (5/22) or pre-neoplastic conditions (1 case, adult polycystic renal disease).

TLCK predominates in the right kidney (14/22 cases, 63.6\%), maximal dimensions varying between 11 and $118 \mathrm{~mm}$ (mean $44.8 \mathrm{~mm}$ ). Four (18.2\%), $11(50 \%)$ and 7 (31.8\%) affected the upper, mid and lower poles, respectively.

Most tumors were hyperechoic (contrasting with TFCC, usually hypoechoic) and hyperdense with low grade heterogenous enhancement on CT and MRI. On pre-contrast MRI TLCK showed high signal on T1 and low signal on T2, as compared to the kidney parenchyma (3). Some presented calcifications. No vascular or urothelial invasion were described, but vessels and renal calices might be displaced. Only two PET scan results are available, both positive to FDG marking $(3,4)$. Abdominal lymph nodes augmentation most commonly did not correspond to metastasis.

Most patients were treated with radical nephrectomy. Partial nephrectomy was used in 6 cases, apparently with the same results. Three patients presented lung metastases $(3,5)$. Curiously, in one case the metastatic nodule was immunoreactive to TTF 1 , as opposed to the kidney specimen (6). Three adults showed abdominal lymph node metastasis $(5,7)$.

Follow-up is limited (median 20 months). Most patients did not show progression of the disease or metastases (Table-1).
Differential diagnosis depends on IHC profile. The diseases to be considered are:

1. Malignancies:

a. Renal metastasis from TFCC from normal or ectopic thyroid tissue (possible on the neck and/or thorax, mainly in the vicinity of the thyroid gland, but not in kidney tissue (6)). Less than 40 cases were described (4), generally associated with widespread metastatic disease (mostly to the lungs, lymph nodes and bones). The metastases are positive to TTF1/TG. A primary tumor should be detectable.

b. Metastasis from struma ovarii $(2 \%$ of the ovarian tumors, malignant in $5-10 \%$ of the cases). Metastases are rare (5\%), preferentially to the liver and peritoneum, and positive to TTF1/ TG (6).

c. Papillary renal cell carcinoma may show patchy "thyroid-like" areas, but the typical architecture usually predominates. IHC is positive to kidney tumor markers.

d. Renal carcinoids may show zonal "follicular" architecture, positive to neuroendocrine markers (synaptophysin, CD 56 and chromogranin). Oncocytomas and metanephric adenomas may also show focal or patchy "follicular" architecture, due to eosinophilic intraluminal deposits in areas of tubular differentiation.

\section{Benign entities:}

a. Kidney "thyreodization" associated to end-stage kidney disease/pyelonephritis, caused by the deposit of colloid-like protein material in the lumina of atrophic distal tubules/collecting ducts. This is a diffuse and bilateral process, not associated with tumors.

TLCK are well circumscribed, yellow/whitish. Hemorrhagic and necrotic areas are common and may present as intratumoral "cysts" $(2,8,9)$. 
Table 1 - Summary of clinical characteristics of the tumors described in the literature plus present case.

\begin{tabular}{|c|c|c|c|c|c|c|}
\hline $\begin{array}{l}\text { Author/publication } \\
\text { year }\end{array}$ & $\begin{array}{c}\text { Age } \\
\text { (years)/ } \\
\text { sex }\end{array}$ & Presentation & Past history & $\begin{array}{l}\text { Local/ } \\
\text { size } \\
(\mathrm{mm})\end{array}$ & Imaging & $\begin{array}{l}\text { Nephrectomy } \\
\text { (T/P)/FU }\end{array}$ \\
\hline \multirow[t]{2}{*}{$\begin{array}{l}\text { Alesssandrini, } 2012 \\
\text { (16) }\end{array}$} & $76 \mathrm{M}$ & Hematuria & Prostate cancer & L UP, 50 & $\begin{array}{l}\text { (CT) Hyperdense, } \\
\text { well vascularized, } \\
\text { necrotic center, } \\
\text { extension to } \\
\text { adipose tissue, } \\
\text { enlarged lymph } \\
\text { nodes (no } \\
\text { metastases). }\end{array}$ & T/ 11 months NED \\
\hline & $41 \mathrm{~F}$ & Incidental & Hodgkin lymphoma & $\mathrm{R} L \mathrm{~L}, 50$ & $\begin{array}{l}\text { (CT) complex } \\
\text { cystic, } \\
\text { hyperdense no } \\
\text { enhancement. } \\
\text { (MRI) solid septa }\end{array}$ & P/ 4 months NED \\
\hline Muscara 2017 (12) & $27 \mathrm{M}$ & Incidental & - & Left UP, 65 & - & P/8 months NED \\
\hline Amin $2009(7)$ & $\begin{array}{c}\mathrm{N}=6(29- \\
83), 3 \mathrm{M} 3 \mathrm{~F}\end{array}$ & All incidental & $\begin{array}{c}1 \text { Colon cancer, } 1 \\
\text { osteosarcoma }\end{array}$ & $\begin{array}{c}\text { 5R 1L/ } \\
1 \text { UP, } 4 \\
\text { MP, } 2 \text { LP/ } \\
19-40\end{array}$ & - & $\begin{array}{c}6 \mathrm{~T} / \mathrm{7}-84 \text { months, } \\
\text { NED }\end{array}$ \\
\hline Dawane 2015 (17) & $49 \mathrm{~F}$ & Incidental & - & L MP 24 & $\begin{array}{l}\text { (CT) contrast } \\
\text { enhancement, } \\
\text { extension to } \\
\text { adipose tissue. }\end{array}$ & $\mathrm{P} / 5$ years, NED \\
\hline Khoja 2014 (18) & $31 \mathrm{~F}$ & $\begin{array}{l}\text { Hematuria, } \\
\text { weight loss, } \\
\text { flank pain (3 } \\
\text { years), anemia }\end{array}$ & $\begin{array}{c}\text { Normal thyroid }(\mathrm{I} / \mathrm{F}) \text {, } \\
\text { normal ovaries }(\mathrm{I})\end{array}$ & L UP 43 & $\begin{array}{c}(\mathrm{CT}) \\
\text { heterogeneous } \\
\text { enhancing, } \\
\text { distorting } \\
\text { collecting } \\
\text { system, } \\
\text { lymph node } \\
\text { enlargement (no } \\
\text { metastases). }\end{array}$ & T/ 21 months NED \\
\hline Jung 2006 (13) & $32 \mathrm{~F}$ & Incidental & $\begin{array}{c}\text { Normal thyroid }(\mathrm{I} / \mathrm{F}) \text {, } \\
\text { normal ovaries }(\mathrm{I})\end{array}$ & R LP/ 118 & $\begin{array}{c}\text { (CT) contrast } \\
\text { enhancing, } \\
\text { hydronephrosis. }\end{array}$ & T/ 6 months NED \\
\hline
\end{tabular}




\begin{tabular}{|c|c|c|c|c|c|c|}
\hline Dhillon 2011 (5) & $34 \mathrm{~F}$ & $\begin{array}{l}\text { Hematuria, flank } \\
\text { pain }\end{array}$ & Normal thyroid (I/F) & $\mathrm{R} \mathrm{MP} / 63$ & $\begin{array}{c}\text { Multiple } \\
\text { pulmonary } \\
\text { nodules (biopsy } \\
\text { "thyroid } \\
\text { carcinoma") }\end{array}$ & $\begin{array}{l}\text { "systemic } \\
\text { treatment" for } \\
\text { thyroid cancer } \\
\text { (1 year) + T } \\
\text { nephrectomy/ } 3 \\
\text { months NED }\end{array}$ \\
\hline \multirow[t]{2}{*}{ Lin 2014 (8) } & $65 \mathrm{M}$ & $\begin{array}{l}\text { Hematuria (4 } \\
\text { years), back pain } \\
\text { (1 week) }\end{array}$ & Normal thyroid (I/F) & R MP, 80 & $\begin{array}{l}\text { Hypoechogenic } \\
\text { hilar mass, } \\
\text { (CT) "renal } \\
\text { carcinoma", } \\
\text { normal fascia/ } \\
\text { lymph nodes. }\end{array}$ & T/ 2 years NED \\
\hline & $59 \mathrm{~F}$ & Incidental & Normal thyroid $(\mathrm{I} / \mathrm{F})$ & R MP, 60 & $\begin{array}{l}\text { Normal fascia/ } \\
\text { lymph nodes. }\end{array}$ & T/ 1 month NED \\
\hline Wu 2014 (4) & $19 \mathrm{~F}$ & Incidental & Leukemia (5 years-old) & R LP 28 & $\begin{array}{c}(\mathrm{CT}) \\
\text { heterogeneous } \\
\text { hyperdense. No } \\
\text { lymph nodes. No } \\
\text { metastasis. PET } \\
(+) .\end{array}$ & $\begin{array}{c}\text { Biopsy + } \mathrm{P} \\
\text { nephrectomy/ } 21 \\
\text { months NED. }\end{array}$ \\
\hline Wang 2017 (2) & $25 \mathrm{~F}$ & $\begin{array}{c}\text { Severe } \\
\text { hypertension } \\
\text { (normal post- } \\
\text { operative) }\end{array}$ & $\begin{array}{c}\text { Normal thyroid }(\mathrm{I} / \mathrm{F}) \text {, } \\
\text { normal ovaries }(\mathrm{I})\end{array}$ & R MP 30 & $\begin{array}{l}\text { (CT) } \\
\text { inhomogenous } \\
\text { enhancement, } \\
\text { calcifications. } \\
\text { Ovaries normal } \\
\text { (imaging). }\end{array}$ & P/ 2 years NED. \\
\hline Ghaouti 2014 (10) & $68 \mathrm{~F}$ & Incidental & $\begin{array}{c}\text { Normal thyroid }(\mathrm{I} / \mathrm{F}) \text {, } \\
\text { normal ovaries }(\mathrm{I})\end{array}$ & R MP 11 & $\begin{array}{c}\text { (MRI) Cystic, no } \\
\text { enhancement }\end{array}$ & $\mathrm{P} /$ no FU reported \\
\hline Volavsek 2013 (11) & $34 ?$ & Incidental & $\begin{array}{l}\text { Nephrolithiasis,polycystic } \\
\text { disease, adult type. }\end{array}$ & $\begin{array}{l}\text { L LP } 50 \\
\text { mm }\end{array}$ & $\begin{array}{l}\text { Hyperechogenic } \\
\text { cyst }\end{array}$ & T/ 6 months NED. \\
\hline Sterlacci 2008 (6) & $28 \mathrm{~F}$ & Incidental & & L MP 44 & $\begin{array}{c}\text { (CT) } \\
\text { Heterogeneous, } \\
\text { no capsule } \\
\text { infiltration, } \\
\text { displacement of } \\
\text { blood vessels. } \\
\text { Left lung nodule. }\end{array}$ & $\begin{array}{l}\text { Thyroidectomy } \\
\text { (presumed } \\
\text { metastatic thyroid } \\
\text { cancer, despite } \\
\text { normal imaging). } \\
\text { Lung lumpectomy. } \\
\text { T nephrectomy/ } 5 \\
\text { years NED. }\end{array}$ \\
\hline
\end{tabular}


Vicens 2014 (3)

Malde 2013 (19)

Our case
$24 \mathrm{~F}$

Hematuria, flank
pain
R MP, 60
(CT) displaying calices,

bilobulated,

peripheral

calcification,

hyperdense,

low grade

enhancement,

peak on delayed

phase. Multiple

pulmonary

nodules, enlarged abdominal

lymphonodes.

(MRI) increased signal T1, low signal

T2, low grade enhancement.

PET scan: mild

FDG uptake. low attenuation, no enhancement.

Flank pain,
oid (I/F) and ovaries I) normal

Flank pain

Thyroid normal (F)

(CT) Complex multiseptated partially cystic, (MRI) no enhancement.$$
\text { Thyrc }
$$

L LP, 58

.

$10 \mathrm{~F}$

\author{
US hyperchoic \\ heterogeneous, \\ CT exophytic \\ anterior superior/ \\ medium pole, \\ heterogeneous \\ enhancement, \\ necrotic and \\ cystic areas, \\ lymph node \\ enhancement (no \\ metastases)
}

T/post op therapy

with sunitinib for

lung metastases. No

FU data.

T. No FU data.

\author{
T. NED, normal \\ imaging after 19 \\ months.
}

$\mathbf{N E D}=$ no evidence of disease; $\mathbf{F U}=$ follow up; $\mathbf{F}=$ female; $\mathbf{M}=$ male; $\mathbf{F u}=$ function; $\mathbf{I}=$ imaging; $\mathbf{U P}=$ upper pole; $\mathbf{M P}=$ mid pole; $\mathbf{L P}=$ lower pole; $\mathbf{L}=$ left $\mathbf{R}=$ right; $\mathbf{T}=$ total; $\mathbf{P}=$ partial 
Histologically there are macro and microfollicles filled with amorphous eosinophilic colloid-like material $(5,10)$, similar to TFCC. The follicles are lined with cuboidal cells with scant eosinophilic cytoplasm, round/oval nuclei and evenly distributed chromatin. Mitotic activity is absent or scarce. There may be focal areas of papillary differentiation, patchy lymphoid aggregates, calcifications (2, 3, 10-12) and cholesterol crystals (12). Fibrous septa presenting muscle and a fibrous pseudocapsule have been described $(7,12)$. No cases presented with vascular or collecting system invasion. Capsular invasion was seen in two cases (11).

The tumor is, by definition, negative to TG/TTF1, positive to epithelial markers (cytokeratyns AE1/AE3, 7, PAX 2 and 8, Vimentin and EMA) and negative to renal tumor markers (WT1, RCC, CD10).

TLCK was described in 2006 (13), is an emerging entity and has not yet been included in the WHO classification of tumors (14). A possible previous case was positive for thyroid IHC markers (15) and is questionable. The predominance of young women suggests some hormonal influence and the relatively high incidence of previous malignancies suggests that previous treatments and/or specific genetic constitutions predispose to TLCK.

Extra-renal extra-thyroid tumors (cholangiocarcinoma, breast and urothelial carcinomas, endolymphatic sac tumor, plasmacytoma, papillary renal cell carcinoma) may also present "follicular" architecture and are negative for TG and TTF1 $(4,7,16)$. Tubular deposits of Tamm-Horsfall glicoprotein are probably the explanation for the colloidal aspect in kidney tumors, including TLCK $(5,10)$.

Primary thyroid tumors are positive to TTF1/TG, except for poorly differentiated or sarcoma-like malignancies. For kidney tumors, the IHC panel includes vimentin, CK 7, AMACR, CCR and CD10 and WT1 in atypical tumors or children. A "thyroid tumor" on a kidney specimen is unexpected and at least one patient was, quite understandably, submitted to a thyroidectomy with the presumed diagnosis of metastatic TFCC, despite normal thyroid imaging (6). Non-reactivity to TG/TTF1 and no primary tumor are the clues to avoid this. Table- 2 summarizes the IHC profiles and differential diagnosis for TFCC, kidney tumors and TLCK.

Surgical resection with clear margins is probably curative, despite the limitations of follow-up data. Partial nephrectomy seems to be as successful as total nephrectomy, but the high proportion of mid pole tumors may impose technical difficulties. Metastases are rare and apparently do not compromise the results in most patients. Adjuvant therapy has not been established.

\section{ACKNOWLEDGEMENT}

We would like to thank Dra. Therezinha C Fonseca de Sá and Dr. Paulo Faria, National Institute of Cancer, Ministry of Health, Rio de Janeiro, Brazil, for their invaluable help with the histological and immunohistochemical diagnosis of the patient, including the microphotographies and immunohistochemical pannels shown in this research. This paper would not be possible without their assistance. 
Table 2 - IHC characteristics of TLCK, other kidney tumors and thyroid tumor.

\begin{tabular}{|c|c|c|}
\hline Tumor & Positive & Negative \\
\hline \multirow[t]{5}{*}{ RCC (Clear cell) } & Vimentin & HMWCK \\
\hline & AE1/AE3 & CK7, CK20 \\
\hline & RCCM & e-cadherin, \\
\hline & PAX2/PAX8 & CD117 \\
\hline & & AMACR \\
\hline \multirow[t]{6}{*}{ RCC (papillary) } & Vimentin & CD117 \\
\hline & AE1/AE3 & \\
\hline & CK7 & \\
\hline & AMACR & \\
\hline & RCCM & \\
\hline & PAX2/PAX8 & \\
\hline \multirow[t]{4}{*}{ Chromophobe RCC/oncocytoma } & e-cadherin & Vimentin \\
\hline & CD117 & AMACR \\
\hline & AE1/AE3 & \\
\hline & CK7 (Chromophobe) & \\
\hline \multirow[t]{6}{*}{ WT } & CD 57 (tubules (+), blastema (-) & CK7 \\
\hline & CK22, CK18, CK8 & Myoglobin \\
\hline & EMA & Chromogranin A \\
\hline & actin & RCC \\
\hline & WT1 & P53 \\
\hline & desmin & Vimentin - blastema, focally (+) \\
\hline \multirow[t]{2}{*}{ TFCC } & PAX 8 & PAX 2 \\
\hline & TTF1, TG, BME1, galactin 3 & \\
\hline \multirow[t]{6}{*}{ TLCK } & CK $7, A E 1 / 3$ & TTF1, TG \\
\hline & PAX 2, 8 & WT1 \\
\hline & Vimentin & RCC \\
\hline & EMA & CD10 \\
\hline & & CEA \\
\hline & & p53 \\
\hline
\end{tabular}




\section{CONFLICT OF INTEREST}

None declared.

\section{REFERENCES}

1. Cajaiba MM, Dyer LM, Geller JI, Jennings LJ, George D, Kirschmann D, et al. The classification of pediatric and young adult renal cell carcinomas registered on the children's oncology group (COG) protocol AREN03B2 after focused genetic testing. Cancer. 2018;124:3381-9.

2. Wang H, Yu J, Xu Z, Li G. Clinicopathological study on thyroid follicular carcinoma-like renal tumor related to serious hypertension: Case report and review of the literature. Medicine (Baltimore). 2017;96:e6419.

3. Vicens RA, Balachandran A, Guo CC, Vikram R. Multimodality imaging of thyroid-like follicular renal cell carcinoma with lung metastases, a new emerging tumor entity. Abdom Imaging. 2014;39:388-93.

4. Wu WW, Chu JT, Nael A, Rezk SA, Romansky SG, Shane L. Thyroid-like follicular carcinoma of the kidney in a young patient with history of pediatric acute lymphoblastic leukemia. Case Rep Pathol. 2014;2014:313974.

5. Dhillon J, Tannir NM, Matin SF, Tamboli P, Czerniak BA, Guo CC. Thyroid-like follicular carcinoma of the kidney with metastases to the lungs and retroperitoneal lymph nodes. Hum Pathol. 2011;42:146-50.

6. Sterlacci W, Verdorfer I, Gabriel M, Mikuz G. Thyroid follicular carcinoma-like renal tumor: a case report with morphologic, immunophenotypic, cytogenetic, and scintigraphic studies. Virchows Arch. 2008;452:91-5. Erratum in: Virchows Arch. 2008;452:471. William, Sterlacci [corrected to Sterlacci, William]; Irmgard, Verdorfer [corrected to Verdorfer, Irmgard]; Michael, Gabriel [corrected to Gabriel, Michael]; Gregor, Mikuz [corrected to Mikuz, Gregor].

7. Amin MB, Gupta R, Ondrej H, McKenney JK, Michal M, Young AN, et al. Primary thyroid-like follicular carcinoma of the kidney: report of 6 cases of a histologically distinctive adult renal epithelial neoplasm. Am J Surg Pathol. 2009;33:393-400.

8. Lin YZ, Wei Y, Xu N, Li XD, Xue XY, Zheng QS, et al. Thyroidlike follicular carcinoma of the kidney: A report of two cases and literature review. Oncol Lett. 2014;7:1796-802.

9. Fadare 0, Lam S, Rubin C, Renshaw IL, Nerby CL. Papillary renal cell carcinoma with diffuse clear cells and thyroid-like macrofollicular areas. Ann Diagn Pathol. 2010;14:284-91.
10. Ghaouti M, Roquet L, Baron M, Pfister C, Sabourin JC. Thyroid-like follicular carcinoma of the kidney: a case report and review of the literature. Diagn Pathol. 2014;9:186.

11. Volavšek M, Strojan-Fležar M, Mikuz G. Thyroid-like follicular carcinoma of the kidney in a patient with nephrolithiasis and polycystic kidney disease: a case report. Diagn Pathol. 2013;8:108

12. Muscara MJ, Simper NB, Gandia E. Thyroid-Like Follicular Carcinoma of the Kidney. Int J Surg Pathol. 2017;25:73-7.

13. Jung SJ, Chung JI, Park SH, Ayala AG, Ro JY. Thyroid follicular carcinoma-like tumor of kidney: a case report with morphologic, immunohistochemical, and genetic analysis. Am J Surg Pathol. 2006;30:411-5.

14. Eble JN, Auter G, Epstein I, Sesterhenn IA (eds). Tumors of the kidney, World Health Organization classification of tumors. Pathology and genetics of tumors of the urinary system of the urinary systems and male genital organs. Lyon: IARC Press; 2004:-87.

15. Angell SK, Pruthi R, Freiha FS. Primary thyroidlike carcinoma of the kidney. Urology. 1996;48:632-5.

16. Alessandrini L, Fassan M, Gardiman MP, Guttilla A, Zattoni F, Galletti TP, et al. Thyroid-like follicular carcinoma of the kidney: report of two cases with detailed immunohistochemical profile and literature review. Virchows Arch. 2012;461:345-50.

17. Dawane R, Grindstaff A, Parwani V, Brock T, White M, Nodit L. Thyroid-like follicular carcinoma of the kidney. Am J Clin Pathol 2015, 144:796-84

18. Khoja A, Almutawa A Binmahfooz A, Aslam M, Ghazzi AA, Almaiman S. Papillary thyroid carcinoma-like tumor of the kidney: a case report. J Surg Pathol 2012, 20:411-5.

19. Malde S, Sheikh I, Woodman I, Fish, Bilagi P, Sheriff MKM. Primary thyroid-like follicular cell carcinoma an emerging entity. Case Reports Pathol 2015: 687427, http://dx.doi.org/10.1155/2013/687427.

Correspondence address:

Lisieux Eyer de Jesus, MD

Av. Presidente Domiciano 52 / 801

Niterói, Rio de Janeiro, RJ, 24210-270, Brasil

Telephone: + 5521 9985-9737

E-mail: lisieux@uol.com.br 